Journal of Mathematics and Statistics 6 (3): 261-264, 2010

ISSN 1549-3644

(C) 2010 Science Publications

\title{
Reliability of Simple 3-Dimnesional Consecutive k-Out-of-n: F Systems
}

\author{
M. Gharib, E.M. El-Sayed and I.I.H. Nashwan \\ Department of Mathematics, Faculty of Science, Ain Shams University, Egypt
}

\begin{abstract}
Problem statement: In this study, the reliability of some special cases of a 3-dimnesional consecutive k-out-of-n: F system and k-within consecutive $(2,2,2)$-out-of- $(\mathrm{m}, 2,2)$ : F system were discussed. Approach: The 3 dimensional systems is a generalization of 1 and 2 dimensional, systems. Projections from 3 dimensional systems to 2 or 1 dimension as special cases is very helpful to find the reliability of these 3 dimensional systems. Results: Many reliability expressions for the 3-dimensional consecutive $\left(\mathrm{k}_{1}, \mathrm{k}_{2}, \mathrm{k}_{3}\right)$-out-of- $(\mathrm{m}, \mathrm{n}, \ell)$ : $\mathrm{F}$ system for some special values of $\mathrm{k}_{1}, \mathrm{k}_{2}, \mathrm{k}_{3}, \mathrm{~m}, \mathrm{n}, \iota$ are presented. Further, the reliability of k-within $(2,2,2)$-out-of-(m,2,2): F system using Markov chains is considered. Conclusion/Recommendations: In general, it is difficult to find the reliability of $\left(\mathrm{k}_{1}, \mathrm{k}_{2}, \mathrm{k}_{3}\right)$ -out-of- $(\mathrm{m}, \mathrm{n}, \mathrm{l})$ : F system, we studied special cases of this system and recommend generalizing the result for any value of $k_{1}, k_{2}, k_{3}, m, n, \iota$. This study presented the reliability formulas of simple 3D systems using results of consecutive k-out-of-n: F systems and 2D consecutive k-out-of-n: F systems and Markov chains.
\end{abstract}

Key words: (1, 2 and 3) D-consecutive k-out-of-n: F system, k-within $\left(\mathrm{k}_{1}, \mathrm{k}_{2}, \mathrm{k}_{3}\right)$-out-of- $(\mathrm{m}, \mathrm{n}, \iota)$ : F system, Markov chains

\section{INTRODUCTION}

The consecutive k-out-of-n: F system has been extensively studied in recent years (Bollinger and Salvia, 1982; Chen and Hwang, 1985; Derman et al., 1982; Shantikumar, 1982; Cluzeau and Keller, 2008; Lambiris and Papastavridis, 1985). The system is specified by $\mathrm{n}$, the number of components, where each component either functions or fails. The system fails if at least $\mathrm{k}$ consecutive components fail. The 2Dconsecutive k-out-of-n: F system was introduced by Salvia and Lasher (1992) by generalizing the notion of the consecutive k-out-of-n: F system. A 2Dconsecutive k-out-of-n: $\mathrm{F}$ system (denoted by $\mathrm{k}^{2} \mid \mathrm{n}^{2}: \mathrm{F}$ ) was defined as a square grid of side $\mathrm{n}$ (containing $\mathrm{n}^{2}$ components). The system fails if there is at least one square of side $\mathrm{k}(1 \leq \mathrm{k} \leq \mathrm{n})$ that contains all failed components. Zuo (1993) proposed a more general model of 2D- consecutive k-out-of-n: F system (denoted by $\mathrm{k}_{1} \mathrm{k}_{2} \mid \mathrm{mn}$ : F). It is a rectangular grid of dimension $m \times n$ (containing m.n components). The system fails if there is at least one rectangle grid of dimension $k_{1} \times k_{2}(1 \leq$ $\left.\mathrm{k}_{1}, \mathrm{k}_{2} \leq \mathrm{m}, \mathrm{n}\right)$ that contains all failed components (Yamamoto and Akiba, 2005). Boehme et al. (1992) and Yamamoto et al. (2008) defined a consecutive $\left(\mathrm{k}_{1}, \mathrm{k}_{2}\right)$ or $\left(\mathrm{k}_{1}, \mathrm{k}_{2}\right)$-out-of- $(\mathrm{m}, \mathrm{n})$ : F system. In this case the system fails if at least one rectangle of dimension $\mathrm{k}_{1} \times \mathrm{k}_{2}$ or $\mathrm{k}_{2} \times \mathrm{k}_{1}$ that contains all failed components occurs.
Similarly the 3D- consecutive k-out-of-n: F system (denoted by $\mathrm{k}^{3} \mid \mathrm{n}^{3}: \mathrm{F}$ ) is defined as a cube of side $\mathrm{n}$ containing $\mathrm{n}^{3}$ components. The system fails if there is at least one cube of side $k(1 \leq k \leq n)$ that contains all failed components (Akiba and Yamamoto, 2002; Akiba et al., 2004). Also more general model of 3D- consecutive kout-of-n: $\mathrm{F}$ systems (denoted by $\mathrm{k}_{1} \mathrm{k}_{2} \mathrm{k}_{3} \mid \mathrm{mnl}$ : F). It is a cuboid of dimension $\mathrm{m} \times \mathrm{n} \times \ell$ (containing m.n. $\ell$ components). The system fails if there is at least one cuboid of dimension $\mathrm{k}_{1} \times \mathrm{k}_{2} \times \mathrm{k}_{3}\left(1 \leq \mathrm{k}_{1}, \mathrm{k}_{2}, \mathrm{k}_{3}, \leq \mathrm{m}, \mathrm{n}, \mathrm{l}\right)$ that contains all failed components. This study gives the reliability of simple 3D systems using results of consecutive 1 and 2 D- consecutive k-out-n: F system in addition to a special case of 3D- dimension system which is k-within (2,2,2)-out-of-(m,2,2): F system, this system consists of $(\mathrm{m}, 2,2)$ cuboid, the system fails if there is at least $\mathrm{k}$ failed components in any $(2,2,2)$ cuboid.

\section{MATRIALS AND METHODS}

The 3-dimensional systems is a generalization of 1 and 2-dimensional, system, projections from 3dimensional systems to 2 or 1 dimension as special cases is very helpful to find the reliability of special cases of the 3 dimensional systems. This study gives the reliability of some special cases of the 3-dimensional systems. To describe the problem, we introduce the following notations and assumptions.

Corresponding Author: M. Gharib, Department of Mathematics, Faculty of Science, Ain Shams University, Egypt 


\section{Notations:}

- p,q: Components reliability (unreliability) of component where $\mathrm{p}+\mathrm{q}=1$

- $g_{k}(n, j)$ : Configuration of no consecutive $k$ failed components from $\mathrm{j}$ through the all $\mathrm{n}$ components which equal $\sum_{i=0}^{\text {gilb }[j k]}(-1)^{i}\left(\begin{array}{c}n-i k \\ j-i k\end{array}\right)\left(\begin{array}{c}n-j+1 \\ i\end{array}\right)$

- $\alpha(m, j):$ Configuration of no connected 2 components in $(\mathrm{m}, 2)$ system.

- $\quad \mathrm{R}(\mathrm{k} ; \mathrm{n} ; \mathrm{p})$ : The reliability of a consecutive k-out-of$\mathrm{n}$ : F system

- $\mathrm{R}\left(\left(\mathrm{k}_{1}, \mathrm{k}_{2}\right) ;(\mathrm{m}, \mathrm{n}) ; \mathrm{p}\right)$ : The reliability of $\mathrm{a}$ consecutive $(\mathrm{k} 1, \mathrm{k} 2)$-out-of-(m,n): F system

- $\mathrm{R}\left(\left(\mathrm{k}_{1}, \mathrm{k}_{2}, \mathrm{k}_{3}\right) ;(\mathrm{m}, \mathrm{n}, \mathrm{l}) ; \mathrm{p}\right)$ : The reliability of a consecutive (k1,k2,k3)-out-of-( $\mathrm{m}, \mathrm{n}, \mathrm{l})$ : $\mathrm{F}$ system

- $\mathrm{R}(\mathrm{k}-(2,2,2) ;(\mathrm{m}, 2,2) ; \mathrm{p})$ : The reliability of a $\mathrm{k}-$ within (2,2,2)-out-of- (m,2,2): F system

- $\mathrm{S}_{\mathrm{r}}$ : Random variable count the failed component of cuboid $(2,2,2)$ in the $\mathrm{r}^{\text {th }}$ layer

- $\mathrm{P}_{\mathrm{k}}$ : Markov transition probability matrix

- $\mathrm{P}_{\mathrm{k}}(\mathrm{ij})$ : Element of transition probability matrix with status $\mathrm{i}$ and $\mathrm{j}$

\section{Assumption:}

- Each component and the whole system can only be either functioning or failed

- All components are mutually s-independent

Lemma: For the k-within (2,2,2)-out-of-(m,2,2): $\mathrm{F}$ system, if $i, j$ the statuses of Markov chains, the transition probability matrix denoted $\mathrm{P}_{\mathrm{k}}$ of the system will be:

$$
P_{k}(i j)= \begin{cases}\left(\begin{array}{l}
4 \\
j
\end{array}\right) p^{4-j} q^{j} & i+j<k \\
0 & i+j \geq k\end{cases}
$$

and:

$$
\mathrm{R}(\mathrm{k}-(2,2,2) ;(\mathrm{m}, 2,2) ; \mathrm{p})=\sum_{\mathrm{j}=0}^{4} \mathrm{P}_{\mathrm{k}}^{\mathrm{m}}(0 \mathrm{j})
$$

Proof: If $i+j<k$ then the number of failed components in the layer $\mathrm{r}+\mathrm{l}$ does not depend on the number of failed components in the layer $\mathrm{r}$, so:

$$
\begin{aligned}
P_{k}(i j)=P\left(S_{r+1}=j S_{r}=i\right) & =\frac{P\left(S_{r+1}=j, S_{r}=i\right)}{P\left(S_{r}=i\right)} \\
= & \frac{\left(\begin{array}{l}
4 \\
j
\end{array}\right)\left(\begin{array}{l}
4 \\
i
\end{array}\right) p^{8-(i+j)} q^{(i+j)}}{\left(\begin{array}{l}
4 \\
i
\end{array}\right) p^{4-i} q^{i}} \\
& =\left(\begin{array}{l}
4 \\
j
\end{array}\right) p^{4-j} q^{j}
\end{aligned}
$$

If $i+j \geq k$ the system will fail, so:

$$
P\left(S_{r}=i, S_{r+1}=j\right)=0 \Rightarrow P_{k}(i j)=0
$$

Hence; the reliability of the system will be of the form:

$$
\mathrm{R}(\mathrm{k}-(2,2,2) ;(\mathrm{m}, 2,2) ; \mathrm{p})=\sum_{\mathrm{j}=0}^{4} \mathrm{P}_{\mathrm{k}}^{\mathrm{m}}(0 \mathrm{j})
$$

\section{RESULT}

The reliability formulas of simple 3D systems: The reliability of a consecutive $(\mathrm{k}, 1,1)$-out-of-(m,l,l): F system is the same as the reliability of consecutive kout-of-n: F system. Therefore from (Zuo, 1993) if $\mathrm{k} \leq \mathrm{m}, \mathrm{n}, \ell$ :

$$
\begin{aligned}
\mathrm{R}((\mathrm{k}, 1,1,) ;(\mathrm{m}, 1,1,) ; \mathrm{p}) & =\mathrm{R}(\mathrm{k} ; \mathrm{m} ; \mathrm{p}) \\
& =\sum_{\mathrm{j}=0}^{\mathrm{m}-\mathrm{g} \operatorname{lilb}[\mathrm{m} \mid \mathrm{k}]} \mathrm{g}_{\mathrm{k}}(\mathrm{m}, \mathrm{j}) \mathrm{p}^{\mathrm{m}-\mathrm{j}} \mathrm{q}^{\mathrm{j}}
\end{aligned}
$$

Also:

$$
\begin{aligned}
\mathrm{R}((1, \mathrm{k}, 1) ;(1, \mathrm{n}, 1) ; \mathrm{p}) & =\mathrm{R}(\mathrm{k} ; \mathrm{n} ; \mathrm{p}) \\
& =\sum_{\mathrm{j}=0}^{\mathrm{n}-\mathrm{gillb}[\mathrm{n} \mid \mathrm{k}]} \mathrm{g}_{\mathrm{k}}(\mathrm{n}, \mathrm{j}) \mathrm{p}^{\mathrm{n}-\mathrm{j}} \mathrm{q}^{\mathrm{j}}
\end{aligned}
$$

and:

$$
\begin{aligned}
\mathrm{R}((1,1, \mathrm{k}) ;(1,1,1) ; \mathrm{p}) & =\mathrm{R}(\mathrm{k} ; 1 ; \mathrm{p}) \\
& =\sum_{\mathrm{j}=0}^{1-\mathrm{gillb}[1 \mathrm{k}]} \mathrm{g}_{\mathrm{k}}(1, \mathrm{j}) \mathrm{p}^{1-\mathrm{j}} \mathrm{q}^{\mathrm{j}}
\end{aligned}
$$

A consecutive (1,1,1)-out-of-(m,n, $\ell)$ : $F$ system reliability is the same as the reliability of a series system consisting of m.n.l components. Therefore:

$\mathrm{R}((1,1,1) ;(\mathrm{m}, \mathrm{n}, 1) ; \mathrm{p})=\mathrm{R}(1 ; \mathrm{mn} \ell ; \mathrm{p})=\mathrm{p}^{\mathrm{m} . \mathrm{n} . \ell}$

The reliability of a consecutive $(\mathrm{m}, \mathrm{n}, \ell)$-out-of$(\mathrm{m}, \mathrm{n}, \ell): \mathrm{F}$ system is the same as the reliability of a parallel system consisting of m.n. $\ell$ components. Therefore: 
$\mathrm{R}((1,1,1) ;(\mathrm{m}, \mathrm{n}, \ell) ; \mathrm{p})=\mathrm{R}(\mathrm{mn} \ell ; \mathrm{mn} \ell ; \mathrm{p})=1-\mathrm{q}^{\mathrm{m} . \mathrm{n} . \ell}$

The reliability of a consecutive (k,1,1)-out-of$(\mathrm{m}, \mathrm{n}, \ell): \mathrm{F}$ system. In this case the system consists of $l$ parallel $(m, n)$-matrix, any $(m, n)$-matrix is considered as a consecutive (k,1)-out-of-(m,n): $\mathrm{F}$ system. In accordance with our definition, the system will fail if at least one row of any $(\mathrm{m}, \mathrm{n})$-matrix includes $\mathrm{k}$ consecutive failed elements occurs. Then the system operating if all of the rows (consider as a consecutive kout-of-m: F system) are operating. Since the elements fail independently, the rows and the matrices fail independently.

The probability that the $(m, n)$ matrix does not fail is equal to the product of the probabilities that the rows of this matrix do not fail, therefore:

$$
\mathrm{R}((\mathrm{k}, 1) ;(\mathrm{m}, \mathrm{n}) ; \mathrm{p})=[\mathrm{R}(\mathrm{k} ; \mathrm{m} ; \mathrm{p})]^{\mathrm{n}}
$$

and:

$$
\mathrm{R}((\mathrm{k}, 1,1) ;(\mathrm{m}, \mathrm{n}, \ell) ; \mathrm{p})=[\mathrm{R}(\mathrm{k} ; \mathrm{m} ; \mathrm{p})]^{\mathrm{n} . \ell}
$$

Analogously for the consecutive (1,k,1)-out-of$(\mathrm{m}, \mathrm{n}, \ell): \mathrm{F}$ system, the reliability function:

$$
\mathrm{R}((1, \mathrm{k}, 1) ;(\mathrm{m}, \mathrm{n}, \ell) ; \mathrm{p})=[\mathrm{R}(\mathrm{k} ; \mathrm{n} ; \mathrm{p})]^{\mathrm{m} . \ell}
$$

And for the consecutive (1,1,k)-out-of-(m,n, $\ell)$ : F system, the reliability function:

$$
\mathrm{R}((1,1, \mathrm{k}) ;(\mathrm{m}, \mathrm{n}, \ell) ; \mathrm{p})=[\mathrm{R}(\mathrm{k} ; \ell ; \mathrm{p})]^{\mathrm{m} . \mathrm{n}}
$$

A consecutive (m,k,l)-out-of-(m,n, $\ell$ ): $\mathrm{F}$ system, in this case, the system consists of $\ell$ parallel $(\mathrm{m}, \mathrm{n}$,$) -matrix.$ Any matrix is considered as a consecutive $(\mathrm{m}, \mathrm{k})$-out-of$(\mathrm{m}, \mathrm{n})$ : F system. In accordance with our definition, the system will fail if $\mathrm{k}$-consecutive columns each including $\mathrm{m}$ failed elements occur of any $(\mathrm{m}, \mathrm{n}$,$) -matrix.$ Then we consider the column as new "element" with failure probability $\mathrm{q}^{\mathrm{m}}$ and reliability $1-\mathrm{q}^{\mathrm{m}}$ and any $(\mathrm{m}, \mathrm{n})$ matrix as a consecutive k-out-of-m: F system, having the reliability $R\left(k ; 1 ; 1-q^{m}\right)$, therefore:

$$
\mathrm{R}((\mathrm{m}, \mathrm{k}, 1) ;(\mathrm{m}, \mathrm{n}, \ell) ; \mathrm{p})=\left[\mathrm{R}\left(\mathrm{n}, \mathrm{k} ; 1-\mathrm{q}^{\mathrm{m}}\right)\right]^{\ell}
$$

Analogously, for consecutive (k,n,l)-out-of$(\mathrm{m}, \mathrm{n}, \ell): \mathrm{F}$ system, the reliability will be:

$$
\mathrm{R}((\mathrm{k}, \mathrm{n}, 1) ;(\mathrm{m}, \mathrm{n}, \ell) ; \mathrm{p})=\left[\mathrm{R}\left(\mathrm{k}, \mathrm{m} ; 1-\mathrm{q}^{\mathrm{n}}\right)\right]^{\ell}
$$

and, for consecutive $(\mathrm{m}, 1, \mathrm{k})$-out-of-(m,n, $\ell)$ : F system, the reliability will be:
$\mathrm{R}((\mathrm{m}, 1, \mathrm{k}) ;(\mathrm{m}, \mathrm{n}, \ell) ; \mathrm{p})=\left[\mathrm{R}\left(\mathrm{k}, \mathrm{n} ; 1-\mathrm{q}^{\mathrm{m}}\right)\right]^{\mathrm{n}}$

and, for consecutive $(\mathrm{k}, 1, \mathrm{l})$-out-of-(m,n, $\ell$ ): $\mathrm{F}$ system, the reliability will be:

$$
\mathrm{R}((\mathrm{k}, 1, \ell) ;(\mathrm{m}, \mathrm{n}, \ell) ; \mathrm{p})=\left[\mathrm{R}\left(\mathrm{n}, \mathrm{k} ; 1-\mathrm{q}^{\ell}\right)\right]^{\mathrm{n}}
$$

and, for consecutive $(1, \mathrm{k}, \ell)$-out-of-(m,n, $\ell)$ : F system, the reliability will be:

$\mathrm{R}((1, \mathrm{k}, \ell) ;(\mathrm{m}, \mathrm{n}, \ell) ; \mathrm{p})=\left[\mathrm{R}\left(\mathrm{m}, \mathrm{k} ; 1-\mathrm{q}^{\ell}\right)\right]^{\mathrm{m}}$

and, for consecutive (l,n,k)-out-of-(m,n, $\ell$ ): $\mathrm{F}$ system, the reliability will be:

$\mathrm{R}((1, \mathrm{n}, \mathrm{k}) ;(\mathrm{m}, \mathrm{n}, \ell) ; \mathrm{p})=\left[\mathrm{R}\left(\mathrm{m}, \mathrm{k} ; 1-\mathrm{q}^{\mathrm{n}}\right)\right]^{\mathrm{m}}$

A consecutive $(\mathrm{m}, \mathrm{n}, \mathrm{k})$-out-of-(m,n, $\ell)$ : $\mathrm{F}$ system $(\mathrm{k} \leq \ell)$. The system fails if $\mathrm{k}$ consecutive $(\mathrm{m}, \mathrm{n})$-matrices each including m.n failed elements. Then we can consider-matrices as new "element" with failure probability $\mathrm{q}^{\mathrm{m} \cdot \mathrm{n}}$ and reliability $1-\mathrm{q}^{\mathrm{m} \cdot \mathrm{n}}$, the system equivalents to consecutive k-out-of- $\ell: F$ system having the reliability $\mathrm{R}\left(\ell, \mathrm{k} ; 1-\mathrm{q}^{\mathrm{m} \cdot \mathrm{n}}\right)$.

Analogously, for consecutive $(\mathrm{m}, \mathrm{k}, \ell)$-out-of$(\mathrm{m}, \mathrm{n}, \ell): \mathrm{F}$ system $(\mathrm{k} \leq \mathrm{n})$, the system equivalents to consecutive k-out-of-n: F system having the reliability $\mathrm{R}\left(\mathrm{n}, \mathrm{k} ;, 1-\mathrm{q}^{\mathrm{m} \cdot \ell}\right)$ and for consecutive $(\mathrm{k}, \mathrm{n}, \ell)$-out-of$(\mathrm{m}, \mathrm{n}, \ell)-\mathrm{F}$ system $(\mathrm{k} \leq \mathrm{m})$, the system equivalents to consecutive k-out-of-m: F system having the reliability $\mathrm{R}\left(\mathrm{m}, \mathrm{k} ; 1-\mathrm{q}^{\mathrm{n} \cdot \ell}\right)$.

A consecutive $(1,2,1)$-or-(2,1,1)-out-of-(m,2,1): $\mathrm{F}$ system. The system consists of $(\mathrm{m}, 2)$-matrix i.e., the reliability of the system is the same as $(1,2)$-or- $(2,1)$ out-of-( $\mathrm{m}, 2)$ : $\mathrm{F}$ system, because it fails if 2 connected components fail, therefore from (El-Sayed, 1998):

$$
\begin{aligned}
& \mathrm{R}((1,2,1)-\text { or }-(2,1,1) ;(\mathrm{m}, 2,1) ; \mathrm{p}) \\
& \quad=\mathrm{R}((1,2)-\text { or }-(2,1) ;(\mathrm{m}, 2) ; \mathrm{p}) \\
& \quad=\sum_{\mathrm{j}=0}^{\mathrm{m}} \alpha(\mathrm{m}, \mathrm{j}) \mathrm{p}^{2 \mathrm{~m}-\mathrm{j}} \mathrm{q}^{\mathrm{j}}
\end{aligned}
$$

$$
\alpha(m, j)=\left\{\begin{array}{lc}
1 & j=0 \\
2 m & j=1 \\
2 & j=m \\
\alpha(m-1, j)+ & 1<j<m \\
2 \sum_{i=1}^{j} \alpha(m-i-1, j-i) & \\
0 & \text { otherwise }
\end{array}\right.
$$


Also:

$$
\begin{aligned}
& \mathrm{R}\left(\begin{array}{l}
(1,2,1)-\text { or }-(2,1,1) ; \\
(2, \mathrm{n}, \mathrm{p}) ; \mathrm{p}
\end{array}\right)=\mathrm{R}\left(\begin{array}{l}
(1,2)-\text { or }- \\
(2,1) ;(\mathrm{n}, 2) ; \mathrm{p}
\end{array}\right) \\
& \quad=\sum_{\mathrm{j}=0}^{\mathrm{n}} \alpha(\mathrm{n}, \mathrm{j}) \mathrm{p}^{2 \mathrm{n}-\mathrm{j}} \mathrm{q}^{\mathrm{j}}
\end{aligned}
$$

and:

$$
\begin{aligned}
& \mathrm{R}\left(\begin{array}{l}
(1,2,1)-\text { or } \\
-(2,1,1) ;(1,2,1) ; \mathrm{p}
\end{array}\right)=\mathrm{R}\left(\begin{array}{l}
(1,2)-\text { or } \\
-(2,1) ;(1,2) ; \mathrm{p}
\end{array}\right) \\
& \quad=\sum_{\mathrm{j}=0}^{1} \alpha(1, \mathrm{j}) \mathrm{p}^{21-\mathrm{j}} \mathrm{q}^{\mathrm{j}}
\end{aligned}
$$

Reliability of k-within (2,2,2)-out-of-(m,2,2): F system.

According the lemma 1 we can directly find the transitive probability matrix and compute the reliability of the system.

Example: Compute $\mathrm{R}(4-(2,2,2) ;(3,2,2) ; \mathrm{p})$ :

$$
\begin{aligned}
& \mathrm{P}_{4}=\left(\begin{array}{cccc}
\mathrm{p}^{4} & 4 \mathrm{p}^{3} \mathrm{q} & 6 \mathrm{p}^{2} \mathrm{q}^{2} & 4 p \mathrm{q}^{3} \\
\mathrm{p}^{4} & 4 \mathrm{p}^{3} \mathrm{q} & 6 \mathrm{p}^{2} \mathrm{q}^{2} & 0 \\
\mathrm{p}^{4} & 4 \mathrm{p}^{3} \mathrm{q} & 0 & 0 \\
\mathrm{p}^{4} & 0 & 0 & 0
\end{array}\right) \\
& \mathrm{P}_{4}^{3}(00)=\mathrm{p}^{12}+8 \mathrm{p}^{11} \mathrm{q}+28 \mathrm{p}^{10} \mathrm{q}^{2}+56 \mathrm{p}^{9} \mathrm{q}^{3} \\
& \mathrm{P}_{4}^{3}(01)=4 \mathrm{p}^{11} \mathrm{q}+32 \mathrm{p}^{10} \mathrm{q}^{2}+114 \mathrm{p}^{9} \mathrm{q}^{3}+208 \mathrm{p}^{8} \mathrm{q}^{4} \\
& \mathrm{P}_{4}^{3}(02)=6 \mathrm{p}^{10} \mathrm{q}^{2}+48 \mathrm{p}^{9} \mathrm{q}^{3}+132 \mathrm{p}^{8} \mathrm{q}^{4}+168 \mathrm{p}^{7} \mathrm{q}^{5} \\
& \mathrm{P}_{4}^{3}(03)=4 \mathrm{p}^{9} \mathrm{q}^{3}+16 \mathrm{p}^{8} \mathrm{q}^{4}+24 \mathrm{p}^{7} \mathrm{q}^{5}+16 \mathrm{p}^{6} \mathrm{q}^{2} \\
& \mathrm{P}_{4}^{3}(03)=4 \mathrm{p}^{9} \mathrm{q}^{3}+16 \mathrm{p}^{8} \mathrm{q}^{4}+24 \mathrm{p}^{7} \mathrm{q}^{5}+16 \mathrm{p}^{6} \mathrm{q}^{2} \\
& \mathrm{R}(4-(2,2,2) ;(3,2,2) ; \mathrm{p})=\sum_{\mathrm{j}=0}^{4} \mathrm{P}_{4}^{3}(0 j) \\
& \mathrm{R}(4-(2,2,2) ;(3,2,2) ; \mathrm{p})=\mathrm{p}^{12}+12 \mathrm{p}^{11} \mathrm{q}+66 \mathrm{p}^{10} \mathrm{q}^{2} \\
& +222 \mathrm{p}^{9} \mathrm{q}^{3}+356 \mathrm{p}^{8} \mathrm{q}^{4}+192 \mathrm{p}^{7} \mathrm{q}^{5}+16 \mathrm{p}^{6} \mathrm{q}^{2} \\
& \text { DISCUSSION }
\end{aligned}
$$

\section{DISCUSSION}

In general, it is difficult to find the reliability of $\left(\mathrm{k}_{1}, \mathrm{k}_{2}, \mathrm{k}_{3}\right)$-out-of- $(\mathrm{m}, \mathrm{n}, \mathrm{c})$ : F system. Thus, in this article, we found the reliability of some special cases in an explicit form. Projections from 3 dimensional systems to 2 or 1 dimension as special cases is very helpful to find the reliability of these 3 dimensional systems. Also we found the reliability of $\mathrm{k}$-within $(2,2,2)$-out-of-(m,2,2): F system using Markov Chains.

\section{CONCLUSION}

In this study, we concluded the reliability of some special cases of $\left(\mathrm{k}_{1}, \mathrm{k}_{2}, \mathrm{k}_{3}\right)$-out-of-( $\left.\mathrm{m}, \mathrm{n}, \mathrm{l}\right)$ : $\mathrm{F}$ system.
Also, the reliability of $\mathrm{k}$-within $(2,2,2)$-out-of-(m,2,2): F system is derived easily using Markov Chains.

\section{REFERENCES}

Akiba, T. and H. Yamamoto, 2002. Upper and lower bounds for 3-dimensional $\mathrm{k}$-within consecutive- $\left(\mathrm{r}_{1}\right.$, $\left.\mathrm{r}_{2}, \mathrm{r}_{3}\right)$-out-of- $\left(\mathrm{n}_{1}, \mathrm{n}_{2}, \mathrm{n}_{3}\right)$ : F system. IEIC Tech. Rep., 102: 1-6. DOI: 10.1142/9789812702685_0002

Akiba, T., H. Yamamoto and Y. Kainuma, 2004. Reliability of a 3-dimensional adjacent triangle: $\mathrm{F}$ triangular lattice system. Proceedings of the 5th Asia Pacific Industrial Engineering and Management Systems Conference, Aug. 27-27, APIEMS, Gold Coast, Australia, pp: 1-10.

Boehme, T.K., A. Kossow and W. Press, 1992. A generalization of consecutive k-out-of-n: F system. IEEE Trans. Reliab., 41: 451-457.

Bollinger, R.C. and A.A. Salvia, 1982. Consecutive kout-of-n: F system networks. IEEE Trans. Reliab., 31: 53-56. DOI: 10.1109/TR.1982.5221227

Chen, R.W. and F.K. Hwang, 1985. Failure distributions of consecutive k-out-of-n: F systems. IEEE Trans. Reliab., 34: 338-341.

Cluzeau, T. and J. Keller, 2008. An efficient algorithm for computing the reliability of consecutive-k-outof-n: F systems. IEEE Trans. Reliab., 57: 53-56.

Derman, C., G.J. Lieberman and M. Ross, 1982. On the Consecutive k-out-of-n: F system. IEEE Trans. Reliab., 31: 57-63.

El-Sayed, E.M., 1998. Algorithm for the reliability of $(1,2)$ or $(2,1)$-out-of- $(\mathrm{n}, 2)$ : F systems. J. Egypt. Math. Soc., 2: 169-173.

Lambiris, M. and S. Papastavridis, 1985. Exact reliability formula for linear and circular consecutive k-out-of-n: F system. IEEE Trans. Reliab., 34: 124-126.

Salvia, A.A. and W.C. Lasher, 1992. 2-dimensional consecutive k-out-of-n: F system models. IEEE Trans. Reliab., 41: 575-578.

Shantikumar, J.G., 1982. Recursive algorithm to evaluate the reliability of consecutive k-out-of-n: F system networks. IEEE Trans. Reliab., 31: 84-87.

Yamamoto, H. and T. Akiba, 2005. A recursive algorithm for the reliability of a circular connected$(\mathrm{r}, \mathrm{s})$-out-of-(m,n): F lattice system. Comput. Ind. Eng., 49: 21-34. DOI: 10.1016/j.cie.2005.01.015

Yamamoto, H., T. Akiba, H. Nagatsuka and Y. Moriyama, 2008. Recursive algorithm for the reliability of a connected-(1,2)-or-(2,1)-out-of-(m,n): $\mathrm{F}$ lattice system. Eur. J. Oper. Res., 188: 854-864. DOI: 10.1016/j.cie.2005.01.015

Zuo, M.J., 1993. Reliability and design of 2-imensional consecutive k-out-of-n: F system. IEEE Trans. Reliab., 39: 488-490. DOI: 10.1109/24.257836 